\title{
Trans-Endodontic Zirconium Oxide Implants: A Clinical Alternative
}

\section{Implantes trans-endodónticos de óxido de zirconia: Una alternativa clínica}

Aguilera-Galaviz Luis DDS, MSc, PhD1; Larios-Cervantes Alexis DDS²; Flores-Reyes Hector DDS, MSc, PhD³; Baltazar Victor DDS, MSc, PhD; Gaitan-Fonseca Cesar DDS, MSc, PhD1

1. Docente-investigador, Maestría en Ciencias Biomédicas, Universidad Autónoma de Zacatecas, Zacatecas, México. 2. Estudiante de Posgrado, Maestría en Ciencias Biomédicas, Universidad Autónoma de Zacatecas, Zacatecas, México. 3. Docente-investigador, Facultad de Estomatología, Universidad Autónoma de San Luis Potosí, San Luis Potosí, México. 4. Docente-investigador, Maestría en Ciencia e Ingeniería de los Materiales, Universidad Autónoma de Zacatecas, Zacatecas, México.

Correspondence to: Dr. César Gaitán Fonseca - cgaitan@uaz.edu.mx

Received: 22-VIII-2018

Accepted: 21-IX-2018

Published Online First: 25-IX-2018

DOI: https://doi.org/10.15517/ijds.v0i0.34661

ABSTRACT

Dental trauma, mainly from the anterior area of the mouth in the incisor teeth at the level of the radicular third, has the extraction of the dental organ as an elective treatment, depending on the severity of the lesion and the site where it presented. This paper reports two cases: one in a young 13-year-old male patient with dental trauma in central incisors, and another in an 18-year-old female patient with radicular reabsorption in central incisors. Both were treated using trans-endodontic implants on teeth 2.1 and 1.1-2.2 each case, respectively. The treatment approach proposed for each case provided good functional and esthetic outcomes. Clinical and radiographic results after 1 year were successful.

\section{KEYWORDS}

Dental trauma; Radicular resorption; Trans-endodontic implants. 


\section{RESUMEN}

El traumatismo dental del área anterior de la boca en los dientes incisivos a nivel del tercio radicular, indica la extracción del órgano dental como un tratamiento electivo dependiendo de la gravedad de la lesión y el sitio donde se presentó. Este artículo reporta dos casos: uno en un paciente masculino joven de 13 años con trauma dental en los incisivos centrales y otro en una paciente de 18 años con reabsorción radicular en los incisivos centrales. Ambos fueron tratados con implantes transendodónticos en los dientes 2.1 y 1.1-2.2 en cada caso, respectivamente. El enfoque de tratamiento propuesto para cada caso proporcionó buenos resultados funcionales y estéticos. Los resultados clínicos y radiográficos después de 1 año fueron exitosos.

\section{PALABRAS CLAVE}

Trauma dental; Resorción radicular; Implantes trans-endodónticos.

\section{INTRODUCTION}

The dentalimplantis definedasabiocompatible metallic or ceramic material that is inserted into maxillary bone tissue for the replacement of a dental organ (1). Within the endodontic area, the technique of trans-endodontic implantation was employed and defined as an artificial extension through the root apex with anchoring in the periradicular bone tissue, with the purpose of improving the crownroot relationship and providing stability to the dental organ present $(2,3)$. The clinical technique of trans-endodontic implantation has reported different materials that have been used; however, with the advent of conventional dental implants, the use of trans-endodontic implants fell into disuse due to technical and clinical differences $(4,5)$.

Currently, with the incorporation of biomaterials such as zirconium oxide and threeDimensional (3D) printing, an attempt has been made to resume this implantation type due to the esthetic, functional, and economic needs that arise in the dental practice (6). This type of implant with the implementation of zirconium oxide for its design and manufacture can provide a functional result, conserving the dental organ in a natural manner. The trans-endodontic implantation technique requires adequate and strategic clinical planning to avoid possible failures due to poor case selection $(7,8)$. According to indications and contraindications (Table 1), there are very specific and limited parameters within which this technique can be developed (6). We development a transendodontic implant in Laboratorio de Ciencias Biomedicas, Área Ciencias de la Salud, Universidad Autonoma de Zacatecas (UAZ) "Francisco Garcia Salinas" and it's were used in this case repots.

The selection of the case and the diagnosis based on the conditions under which the patient is located leads us to decide whether or not to apply the clinical treatment, which has certain advantages over the traditional technique of a dental implant. The advantages are the following: to preserve natural teeth; maintaining of the natural epithelial junction; the implant prolongs the root length; with no corrosion, and the technique diminishes abnormal dental mobility. On the other hand, this clinical process entertains some disadvantages, including aging and fracture of the implant, bone rejection, probably formation of periapical lesion, and its being an unusual technique $(1,9)$.

Compared with conventional implants, the objective is to preserve the natural teeth, since the implant is placed through the root canal, principally in organs with horizontal trauma and 
indication is dental extraction. With the latter, we ensure a natural epithelial union of the dental organ itself with periodontal structures, and that the pin has the function of prolonging the length of the root and decreasing the abnormal mobility of the tooth $(1,9)$. The aim of this paper was to describe two case reports about of transendodontic implant technique.

Table 1. Indications and contraindications of trans-endodontic implants.

\begin{tabular}{|c|c|}
\hline Indications & Contraindications \\
\hline $\begin{array}{l}\text { Bone loss, in particular the involvement of a single tooth, where } \\
\text { extraction and replacement are difficult. }\end{array}$ & Periodontal damage evident without alternative treatment. \\
\hline $\begin{array}{l}\text { Horizontal fracture of a tooth that requires removal of the apical } \\
\text { segment and the remaining coronal portion is too weak to remain } \\
\text { due to an unfavorable crown-root relationship. }\end{array}$ & Vertical fracture. \\
\hline $\begin{array}{l}\text { Pathological reabsorption of the apex of the root due to chronic } \\
\text { abscess. }\end{array}$ & Root resorption of more than two thirds of the root. \\
\hline Teeth without pulp with unusually short root. & Teeth with pathological mobility. \\
\hline Superior anterior teeth. & Antero-inferior and multiradicular teeth. \\
\hline
\end{tabular}

\section{CASE REPORTS}

\section{CASE 1}

Male patient 13 years of age who comes to a consultation referred by the Pediatric Dentistry Clinic. The person accompanying the patient reports that the child had an accident and that his teeth were broken. The child was taken to the clinic after not obtaining a solution with which she was satisfied, and he was taken to the Pediatric Dentistry Clinic, where he underwent some treatments. The patient was subsequently is referred to the CLIMACB.

At the time of the clinical examination, the patient was observed with a splint on the four upper central incisors, the gum was red in color, smooth, bright, and with an increase in volume in the upper anterior, which presented a sounding depth of 5 $\mathrm{mm}$ (Figure 1a). The radiographic examination showed a radio-lucid line located in the middle third of dental organs 1.1 and 2.1 (Figure 1b).

Once the clinical history was completed, the treatment options were evaluated and the patient and his parent were offered the option of placing the trans-endodontic implant, the acceptance of this by both, and the signing of the informed consent document.

Surgical intervention was performed, which initiated local anesthesia (Lidocaine HCL with epinephrine $2 \% 1: 100000$, ZEYCO) of the area, management of hard and soft tissues, preparation of the root canal (implant burs IMPLANETTM system) and open surgery to expose the apex of the root. This then continued with placement of the trans-endodontic implant (manufactured in UAZ) inside of root canal and its cementation (RelyX'M U100, 3M); sutured (VICRYL $\left.{ }^{\circledR}, E T H I C O N\right)$, and the composite (Filtek ${ }^{\mathrm{TM}} \mathrm{Z250}$, 3M) was applied for the final sealing of the endodontic access. At the end of the procedure an $x$-ray was taken to confirm correct placement of the implant.

A 360-day follow-up was carried out during which an $\mathrm{x}$-ray was taken every 30,180 , and 360 days (figure 2) as a method of osseointegration evaluation. During this process, the trabecular formation around the implant can be observed that, in the radiography, is shown as a radio- 
opaque area, in addition to the clinical observation and absence of signs and symptoms such as pain, inflammation, bleeding, infection, and mobility.

\section{CASE 2}

An 18-year-old female patient who arrives at the referral clinic of the Multidisciplinary Clinic of Zacatecas (UAO/UAZ). The patient reports having used braces in the past that caused the roots of her teeth to become small and, in addition, to move.

At the time of the clinical examination, the upper central incisors (1.1 and 2.1) are observed with a greenish hue, the gingiva is bright red in color, with a sounding depth of around $3 \mathrm{~mm}$. On radiographic examination, it can be observed that the upper central incisors possess a reduced root size (Figure 3).

Once the clinical history was completed, the treatment options were evaluated and the patient was offered the option of placing the transendodontic implant and, on this being accepted, informed consent was signed.
Surgical intervention was performed, which initiated local anesthesia (Mepivacaine HCL with epinephrine 2\% 1:100 000, ZEYCO) of the area, management of hard and soft tissues, preparation of the root canal (implant burs IMPLANETTM system) and open surgery to expose the apex of the root. This then continued with placement of the trans-endodontic implant (manufactured in UAZ) inside of root canal and its cementation (RelyXTM U100, 3M); sutured (VICRYL $®, E T H I C O N)$, and the composite (Filtek ${ }^{\text {TM } Z 250,3 M) ~ w a s ~ a p p l i e d ~ f o r ~ t h e ~}$ final sealing of the endodontic access. At the end of the procedure an x-ray was taken to confirm correct placement of the implant.

A 360-day follow-up was carried out during which an x-ray was taken every 30, 180, and 360 days (Figure 4) as a method of osseointegration evaluation in which the formation of bone trabeculation around the implant can be observed during this process. The latter is shown in the radiography as a radio-opaque area, in addition to clinical observation and absence of signs and symptoms such as pain, inflammation, bleeding, infection, and mobility.

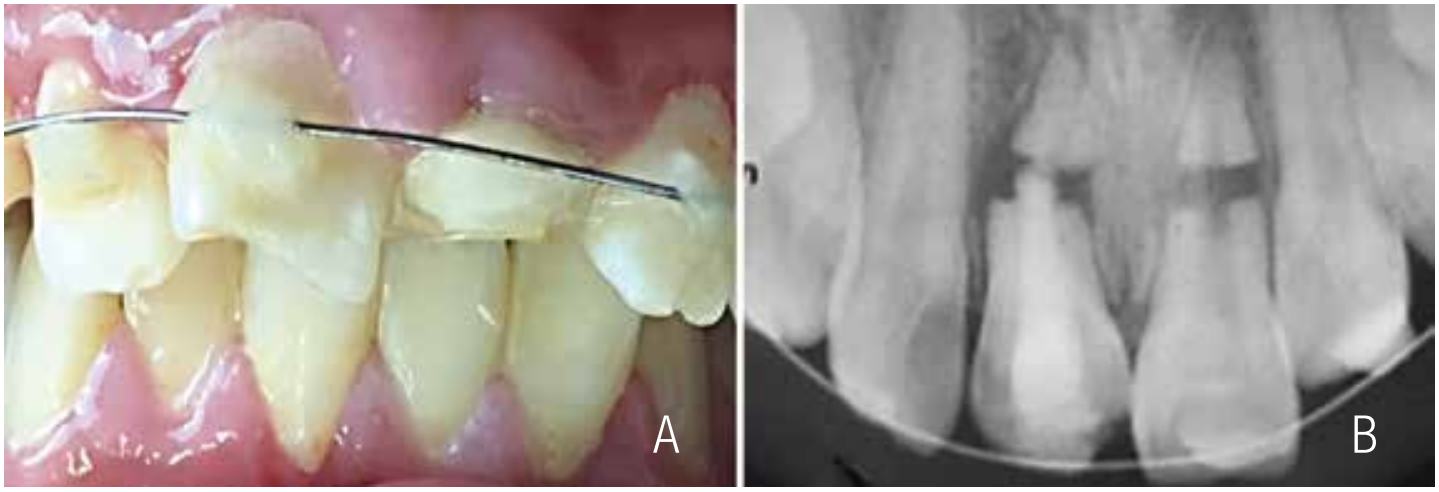

Figure 1. Initial photograph. 1a: intraoral examination in which a splint is observed that extends from canine to canine (1.3 to 2.3 dental organs) and the gum is inflamed, reddish, and shiny. $1 \mathrm{~b}$ : an x-ray was taken of the same area, in which a radiolucent area can be seen horizontally at a level of the middle third. 

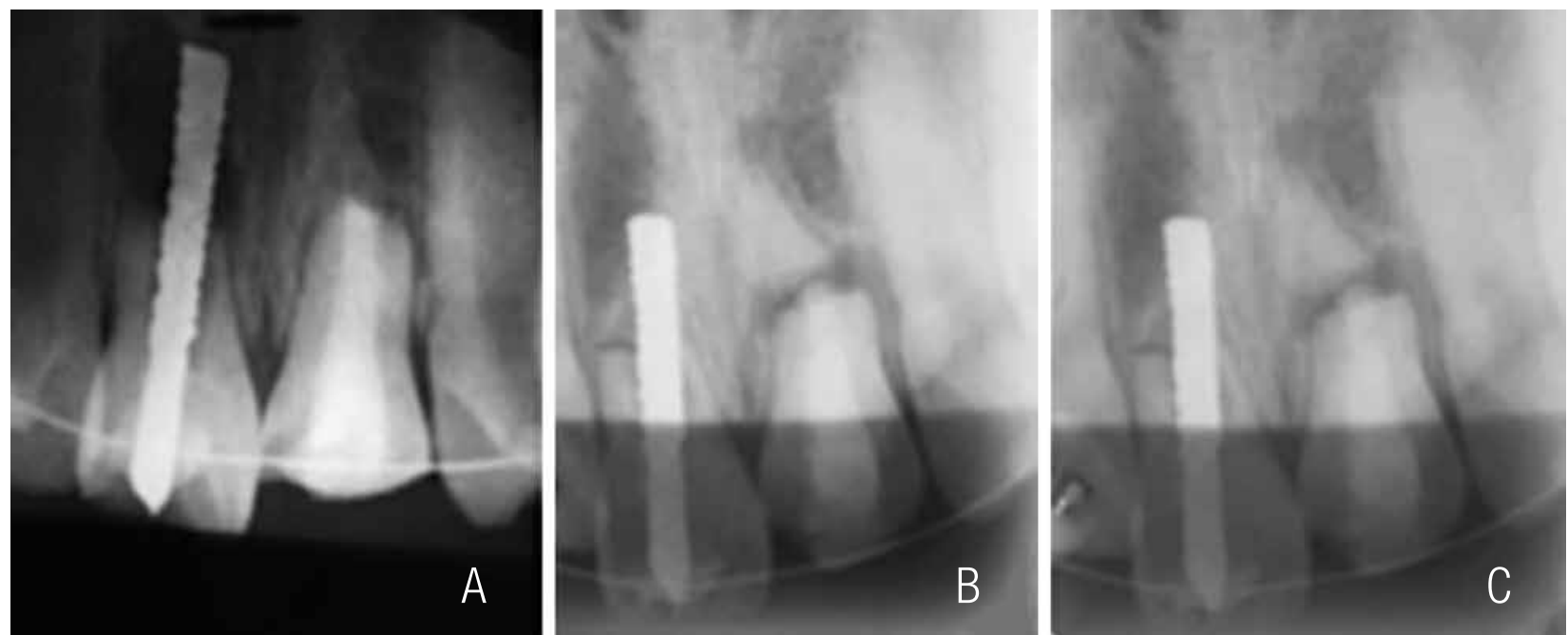

Figure 2. Follow-up radiographs. 2a: $X$-ray at 30 days, $2 \mathrm{~b}: \mathrm{X}$-ray at 180 days, $2 \mathrm{c}$ : $\mathrm{X}$-ray at 360 days, with the passage of months, one is able to observe the formation of the bone trabeculate.
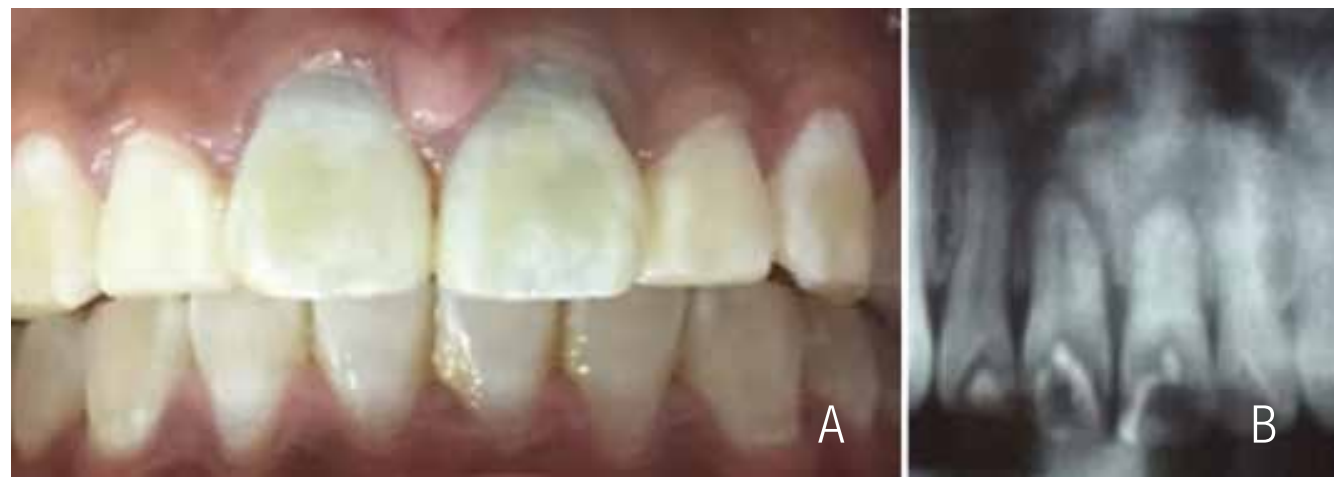

Figure 3. Initial photograph. 3a: intraoral examination in which a greenish tone is appreciated in the cervical area of dental organs 1.1 and 2.1 . 3b: a panoramic radiograph in which one is able to appreciate that the root of dental organs 1.1 and 2.1 are diminished.
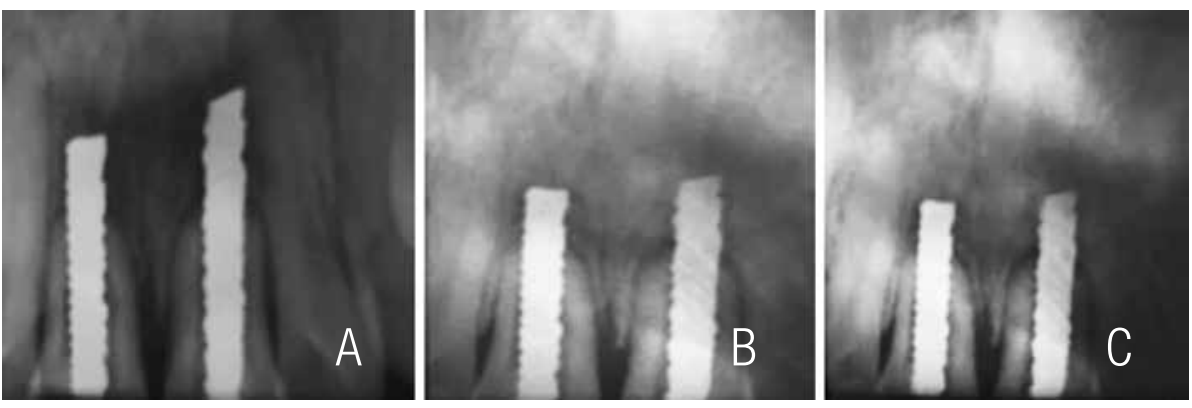

Figure 4. Follow-up radiographs. 4a: X-ray at 30 days, $4 b: X$-ray at180 days, $4 c$ : $X$-ray at 360 days, we can see in the radiographs how a radiopaque zone begins to appear around the implant. 
DISCUSSION

Chercheve in 1962 (10) opted to perform an implant as a "screw", this affording us part of the guidelines that are today included in the design for the trans-endodontic implant. The latter took into account the portion of the implant that is in contact with the bone and the portion that is cemented inside the root canal.

In the study by Kokane (11), the use of transendodontic implants had patient expectations for the patient that indicated that it is a quick, effective, and cost-effective treatment to save the tooth. As in this investigation, patients referred it to be an ideal treatment, since after 1 year of follow-up, the results have been better than expected.

Although it is described by different authors with different types of studies that have in common the use of biomaterials for dental applications, the concept in implantology that the majority of us seek is osseointegration; however, the way to prove that this is present is very restricted. Manfro et al. (12) carried out a study in which the authors placed 60 implants in patients to evaluate osseointegration within a period of 60 days. After these 60 days had elapsed, the authors removed the placed implant that had been set in place in order to histologically evaluate the presence of the osseointegration. Due to the nature of the study, the preservation of the dental organ is essential for the success of the trans-endodontic implant; thus, we could consider, as an aberration the removal of the dental organ, to check osseointegration (13). Therefore, different methods were employed to evaluate the osseointegration, such as dental mobility, the absence of an infectious process, together with rejection by the tissues and the presence of radio-opaque zones indicative of the formation of bone tissue around the implant.

The radiographic examination performed every 90 days can provide us with an idea of the osseointegration process, observing the radioopaque zone located around the trans-endodontic. Depprich implant (14), in the same manner, the considerable decrease of dental mobility comprises another favorable parameter that could afford us indications of the signs and symptoms, such as pain, inflammation, or bleeding.

According with this paper, the patients were according in accepted the clinical procedure with inform consent. In the other hand this procedure was explained for them and the advantages and disadvantages. In case of the benefits/cost, principally the dental organs were a complicated prognostic (extraction was indicated) however with this technique was possible to presser dental organ in patients.

In general, this technique has biological conditions similar to traditional implant, the principal aim is obtaining an osseointegration for avoid the failure and give stability to the dental organ. This procedure only was indicated for central and lateral maxilar incisors and is contraindicated in canine, premolar and molars. Finally, in case the implant not obtained osseointegration a dental organ need to extraction.

\section{CONCLUSION}

The use of trans-endodontic zirconium oxide implants was a fundamental and very successful tool in the cases presented in this study since, although the aesthetic factor was important for patients, the connotation of wanting to preserve the dental organ functionally was the favorite factor for the total satisfaction of the placement of the implants. In addition to this, after 1 year of followup, the patients continue with the dental implant in optimal conditions and they referred not feeling any type of negative effect. Therefore, we are able to ensure that the material possesses the capacity for osseointegration, and that the expectations of the study were exceeded. 


\section{REFERENCES}

1. Larios A., Gaitán C., Aguilera L., Aceves M. Diseño, fabricación y evaluación clínica de implantes trans-endodónticos de Óxido de Zirconio. RelbCi 2016; 3 (1): 64-70. [In Spanish, English abstract].

2. Yadav R., Tikku A., Chandra A., Wadhwani K. Singh M. Endodontic implants. Natl J Surg 2014; 5 (1): 70-3.

3. Santos A., Cava C., Robello J. Implante transendodontico de Cromo-Cobalto. KIRU 2004; 1 (2): 109-116.

4. Weine F. Survival of the endodontic endosseous implant. J Endod 1993; 19 (10): 524-8.

5. Mittal S., Kumar T., Aggarwal V., Bansal R., Kaur D. Endodontic stabilizers for treating mid root fractures. J Interdiscip Dentristy 2015; 1 (2): 108-10.

6. Larios A., Aguilera A., Flores H., Gaitán C. et al. Chemical and microscopy characterization of trans-endodontic implants. Odovtos Int J Dent Sc 2017; 20 (2): 81-89.

7. Parmar G. Custom-fabricated endodontic implants: report of two Cases. J Endod 2000; 26 (5): 301-3.
8. Sumi Y. Conservation of severely traumatized teeth using endodontic implants. A case report. J Oral Maxillofac Surg 1998; 56 (2): 240-2.

9. Almagro S., Balbín N., Jiménez M. Dientes estabilizados con implantes endodónticos intraóseos como pilares de prótesis. Rev Cubana Estomatol [online] 2003; 40: 0-0.

10. Cava C. Extirpación de canino retenido y estabilización dental mediante implantes endodónticos. KIRU 2009; 6 (1): 46-52.

11. Vandana B., Swapnil N. Management of grade III mobile anterior tooth in function using endostabilizer- a case report. J Clin Diagn Res 2014; 8 (12): ZD06-ZD07.

12. Manfro R., Bortoluzzi M., Fabrís V., Elías C. Clinical evaluation of anodized surface implants submitted to a counter torque of $25 \mathrm{Ncm}$ after 60 days of osseointegration: study in humans. J Maxillofac Oral Surg 2015; 14 (1): 1-6.

13. Liu Y., Zhou Y., Jian T., et al. Evaluation of the osseointegration of dental implants coated with calcium carbonate: an animal study. Int J Oral Sci 2017; 9 (3): 133-138.

14. Depprich R. Osseointegration of zirconia implants compared with titanium: an in vivo study. Head Face Med 2008; 11 (4): 30. 